University of Nebraska - Lincoln

DigitalCommons@University of Nebraska - Lincoln

Faculty Publications, UNL Libraries

Libraries at University of Nebraska-Lincoln

January 2008

Federal government documents: Dead or alive

Charles D. Bernholz

University of Nebraska-Lincoln, cbernholz2@unl.edu

Follow this and additional works at: https://digitalcommons.unl.edu/libraryscience

Part of the Library and Information Science Commons

Bernholz, Charles D., "Federal government documents: Dead or alive" (2008). Faculty Publications, UNL Libraries. 127.

https://digitalcommons.unl.edu/libraryscience/127

This Article is brought to you for free and open access by the Libraries at University of Nebraska-Lincoln at DigitalCommons@University of Nebraska - Lincoln. It has been accepted for inclusion in Faculty Publications, UNL Libraries by an authorized administrator of DigitalCommons@University of Nebraska - Lincoln. 


\title{
Federal government documents: Dead or alive
}

\author{
Charles D. Bernholz ${ }^{1}$ \\ Love Memorial Library, University of Nebraska-Lincoln, \\ Lincoln, NE 68588, USA
}

Keywords: GPO, FDLP, Government documents

The United States Government Printing Office (GPO) and the Federal Depository Library Program (FDLP) are at a crossroad. The resignation by Bruce James, the Public Printer, has stalled the full implementation of his promised free and unrestricted digital access by all citizens to United States government documents. ${ }^{2}$ The publication of $A$ Strategic Vision for the 21st Century in December 2004 had declared that the goal of the GPO was "to digitize all retrospective documents that can be authenticated back to the Federalist Papers. We expect to complete $70 \%$ of this task by December $2007 . " 3$

The last few years for the federal government documents community have been plagued by endless questions and arguments of whether such electronic materials will meet, and satisfy, the needs of this nation and its organizations. These inquiries reach far beyond just sheer user or GPO convenience, or World Wide Web access to relevant assets. On the one hand, the call for the digitization, for example, of the United States Reports has fallen upon deaf ears in the court system, for some very valid reasons. Yet on the other hand, the opportunity to attenuate the costs and headaches associated with printing and delivering all FDLP items is a siren call for any member - or prospective member - of

\footnotetext{
${ }^{1}$ Charles D. Bernholz is the Government Documents Librarian at the University of Nebraska-Lincoln. He has a B.A. from Northeastern University; an M.A. from the University of Guelph; and an MLS from the State University of New York at Buffalo. His research interests focus upon treaties created by the Indian Nations and the governments of North America, and upon the development of federal Indian law in the United States and in Canada.
}

${ }^{2}$ Federal Computer Week. Retrieved September 15, 2007, from http://www.fcw.com/article94071-04-13-06-Web.

${ }^{3}$ A Strategic Vision for the 21st Century. Retrieved September 15, 2007, from http://www.gpo.gov/congressional/pdfs/04strategicplan.pdf; see p. 5. 
Congress. The new mandate requiring all federal agencies to release their own specialized materials in digital format is one way to dispense with that old GPO building that was the source of so many of the Public Printer's bon mots during his presentations. ${ }^{4}$ The fresh rules, though, are also a mechanism to assure that the expense of creating and of supporting these desired public federal data is shared by other sectors of the government.

However, only a small proportion of the citizens of this country gets information - federal or not-from the Internet. Table 1148, "Household Internet Connections By Type," in the 2006 Statistical Abstract, reported that, in 2003, 54.6\% of all sampled households61,481 homes - had Internet access, but that just 35.8\% (or 21,973 residences, to be exact) had anything other than slow, dial-up service. ${ }^{5}$ Unless this latter group endures long downloading times, it would appear that many of these citizens must get their federal information elsewhere, perhaps through their local library, just as they have since the idea of an effective FDLP began over a century ago. There is no doubt that, once there, library patrons might have the opportunity in the future to access the Web to manipulate those promised digitized Federalist Papers from the GPO, but for the most part, the concept that a local library is nothing more than an Internet café to facilitate surfing government documents is absurd. The "Keeping America Informed" Web page ${ }^{6}$ states that the "Federal Depository Library Program makes available to the public no-fee access to information produced by Federal agencies." Further, Title 44 of the United States Code identifies all those unique yet still ordinary libraries (and the necessary steps to acquire even more of them-like those of the tribal colleges) that are in place to supply these very documents. Moreover, with the Public Printer's confession, at the October 2006 Federal Depository Library Conference and Fall Depository Library Council meeting, that Congress is not particularly enthusiastic now to finance the retrospective conversion of all documents back to the Federalist Papers, we will all be in need, for the near future at least, of those quite un-chic but steadfast libraries. ${ }^{7}$

The complementary structure of selective and regional depositories was designed to coordinate access to federal documents. This year, the country's library and educational

\footnotetext{
${ }^{4}$ Many of these gems centered upon the debilitating expense of maintaining the "78 elevators, 144 bathrooms, and a sometimes-leaky roof" in the building in which the GPO has resided since 1860 . See "GPO Seeking A New Home," The Washington Post, 11 February 2004, E1. Retrieved September 15, 2007, from http://www.gpo.gov/congressional/annualreports/04annrep/gpo_seeking_a_new home.pdf.

${ }^{5}$ A Nation Online: Entering the Broadband Age. Table 1148. Household Internet Connection by Type: 2003. Retrieved September 15, 2007, from http://www.census.gov/compendia/statab/2006/tables/ 06s1148.xls.

${ }^{6}$ Keeping America Informed: The Federal Depository Library Program. Retrieved September 15, 2007, from http://www.gpo.gov/su_docs/fdlp/pr/keepam.html.

${ }^{7}$ Such a revelation by the Public Printer is a bit disconcerting and confusing, especially when coupled with the GPO's Annual Report for 2006, The Faces of the GPO. Retrieved September 15, 2007, from http://www.gpo.gov/congressional/annualreports/06annrep/2006-GPOAnnualReport.pdf. In his November 2006 opening remarks in that Report, Mr. James cited the Strategic Vision for the 21st Century document as the basis for the restructuring of the GPO, and stated that "Our Digital Media Services capability will make it possible to digitize all retrospective Government documents that can be authenticated back to the earliest days of the Nation. In 2006, we began a project to demonstrate our digitization capabilities, and we expect to move forward with it in 2007" (The Faces of the GPO, p. 3; emphasis added).
} 
communities are celebrating the centennial of the inclusion of land-grant institutions into the FDLP, a pivotal win-win decision that has bound together tightly the academic underpinnings of this country and the circulation of its government's publications. For the most part, much of the hand wringing during Mr. James' tenure over the future of the GPO and of the FDLP was linked to a perceived chasm that might be induced by the creation of a fully digitized documents collection. At least one of the concerns was that full Internet accessibility to a complete federal ensemble would somehow reduce the need for a synchronized program of selective and, especially, of regional libraries. The fear, at least in the hearts of some librarians, was that the present FDLP would somehow be dismantled or damaged to an unspecified degree in the process of this "electronic transition."

Regardless of whether these threats to the FDLP - and surely, by association, to libraries in general - are real or imaginary, we cannot permit these outcomes to occur. It is for us solely a question of whether our patrons' or our neighbors' or our families' federal information needs will be met. As just a single example, the slowly arriving flood of all those retiring post-war Boomers will demonstrate like never before our importance as documents librarians, in addition to the general profound need by many of our special resources. All those Social Security questions. All that health care information. All the data that ties this country together. We are getting these inquiries in our libraries already, are we not? All this - yet unavailable in a fully digitized GPO world for those living without reliable Internet access. Not everyone lives inside the Beltway, or around the District, or in a major metropolitan area.

This scenario carries a corollary. The need for documents librarians will not disappear, even if the proposed full digitization is accomplished. Have no fear-there will always be a place for us, whether access to federal documents is through paper or pixel-but the short-term, fashionable, geeky perspective to "just-digitize-everything-since-the-Federalist-Papers-and-put-it-up-on-the-'Net" will not cut it. Our patrons will need us, not just their computer mice, to acquire the answers to their questions.

Those of us who were lucky enough to fall in love with documents have learned a truth that many of our colleagues have not. Let us not throw away that gift or insight. We must remember that it is our responsibility to serve our documents patrons well, and to furnish aggressive mentoring to anyone who thinks that he or she might have seen the light and, thereby, might wish to become a member of our calling. But we must stay attuned always to the task of vigorously defending documents, as well.

We will have a new Public Printer to replace Mr. James, and then others after that one too. Each will have his or her own political hypotheses regarding the correct path for the GPO and for federal materials, delivery format notwithstanding. If, however, the documents community defaults; if it does not stand up as a cohesive entity; or if it fails, in the face of these proposals from forthcoming Public Printers, to boldly help formulate an effective information environment that will sustain what we each know and believe is correct for documents, then our patron saint, Adelaide Hasse, will have been a model documents librarian - and will have fought back against the dictates of an entrenched system-for naught.

Marcel Proust wrote "What we call our future is the shadow that our past projects in front of us." For the federal documents universe, this is only partially correct. We should 
attend more to how it has felt to be documents librarians, instead of trying to reconcile the past with all those wishful digital delivery monologues. A lack of courage on our part now — or relying solely upon that handy silhouette — will jeopardize the prospect of tomorrow's federal documents and their use. That absence of daring, or the use of that crutch, will guarantee that whatever results we are handed in our silence will be precisely what we deserve. 